\title{
An Analysis of State Statutes On Capital Juror Disqualification and a Proposal for an Exploratory Statute
}

Journal of Criminal Justice and Law

Volume 1, Issue 1, pp. 1-21 (2017)

(C) University of Houston-Downtown

\section{Alexander H. Updegrove' and Rolando V. del Carmen'}

\begin{abstract}
Despite increasing unease with the death penalty in the United States, many states continue to conduct capital trials purged of jurors categorically opposed to the death penalty. Death-qualified juries are of great concern because they are more likely to convict and sentence a defendant to death. An analysis of capital juror disqualification criteria in state statutes reveals states heavily emphasize disqualifying prospective jurors who oppose the death penalty, but devote scarce attention to addressing procedures for disqualifying prospective jurors with pro-prosecution and pro-death biases. Roughly half of the states where capital punishment remains legal do not have statutes specifically addressing capital jurors' disqualification criteria; the half that do have statutes with provisions that are woefully inadequate. This article concludes by proposing an exploratory statute designed to increase fairness in current capital juror disqualification practices.
\end{abstract}

\section{Keywords}

death penalty, capital punishment, death qualification, juror

\section{Introduction}

It is common knowledge that battles are won or lost long before the actual fight begins. Military leaders select terrain that offers them the greatest advantage over the enemy in order to increase their likelihood of victory. During the American Civil War, when artillery ranges were shorter, elevation played a key role in determining which side won the battle. Some historians cite General

\footnotetext{
' College of Criminal Justice and Criminology, Sam Houston State University, Huntsville, TX, USA

Corresponding Author:

Alexander H. Updegrove, College of Criminal Justice and Criminology, Sam Houston State University, Box 2296, Huntsville, TX, 77341, USA

Email: ahu002@shsu.edu
} 
Ewell's failure to secure the hills of Gettysburg on the first day as the pivotal moment in the most important battle waged during the five year conflict. ${ }^{1}$ Although the fate of the Confederate States of America likely never rested on Ewell to the degree some historians allege, the principle still stands that battles are won or lost by controlling important terrain.

In the context of the United States' continued historical jurisprudence with death penalty cases, the same holds true: those who occupy a stronger position at the outset of the conflict are more likely to prevail. The United States' reliance on an adversarial legal system sets the stage for the prosecution to wage war against the defense, with the life of the capital defendant hanging in the balance. As one legal scholar notes, "most trials are won or lost in jury selection."2 Deathqualification - the practice of questioning prospective capital jurors during voir dire to determine who is sufficiently biased for or against the death penalty to warrant removal from the jury ${ }^{3}$-has long been acknowledged as giving the prosecution an unfair advantage. Stated bluntly, "the fighting over death qualification is related to the pink elephant in the room, which is that death qualification helps the prosecution win the case." 4 Other scholars refer to this prosecutorial advantage as "a clear slant," 5 "a serious problem of tyranny," ${ }^{6}$ and "one of the finest tools of the prosecutor." ${ }^{7}$ Regardless of intent, death-qualification gives voice to prospective jurors willing to uphold the status quo of the death penalty within a state while silencing objectors. ${ }^{8}$ The effect is to require the defense to labor uphill throughout the trial until finally they must storm the prosecution-controlled terrain much like Pickett's charge. ${ }^{9}$ In comparison to the 498 men killed from Picket's division, ${ }^{10} 1,442$ capital defendants have been executed since 1976 partially as a consequence of the prosecution controlling the jury. ${ }^{11}$

Although the U.S. Supreme Court appears to have largely moved on from refining capital juror disqualification procedures - the current criteria for disqualification were established in $1985^{12}-$

\footnotetext{
${ }^{1}$ See Terry L. Jones, General Ewell's Dilemma. N.Y. TIMES: OPINIONATOR (July 2, 2013, 11:39 AM), http://opinionator.blogs.nytimes.com/2013/07/02/general-ewells-dilemma/.

2 See John H. Blume, Sheri Lynn Johnson, \& A. Brian Threlkeld, Probing "Life Qualification" through Expanded Voir Dire, 29 Hof. L. Rev. 1209, 1209 (1996).

${ }^{3}$ See Brooke M. Butler \& Gary Moran, The Role of Death Qualification in Venirepersons' Evaluations of Aggravating and Mitigating Circumstances in Capital Trials, 26 L. HuM. BeHAV. 175, 176 (2002).

${ }^{4}$ Symposium, Open Discussion: Capital Jury, 80:1 IND. LaW J. 60, 64 (2005).

${ }^{5}$ Adam M. Clark, An Investigation of Death Qualification as a Violation of the Rights of Jurors, 24 Buff. PuB. INT. L.J. 1, 38 (2005).

${ }^{6} / d$. at 53.

${ }^{7}$ Open Discussion: Capital Jury, supra note 4.

${ }^{8}$ G. Ben Cohen \& Robert J. Smith, The Death of Death-Qualification. 59 CASE W. RES. L. ReV. 87, 89 (2008).

${ }^{9}$ See Robert C. Cheeks, Nothing But Glory Gained - Account of Pickett's Charge at Gettysburg, America's Civil War, Sept. 1990, at 32. On the final day at Gettysburg, Lee ordered Picket to have his division march uphill over a long distance in the open while taking heavy artillery fire. Id. Although the Confederates suffered heavy casualties, a few soldiers crossed the enemy's position but were ultimately unable to hold it. Id.

10 See Earl J. Hess, Pickett's Charge -- The Last Attack at Gettysburg 333 (1st ed. 2010).

11 Number of Executions by State and Region Since 1976, DeATH Penalty INFo, http://www.deathpenaltyinfo.org/number-executions-state-and-region-1976 (last updated Dec. 9, 2016).

12 Wainwright v. Witt, 469 U.S. 412 (1985).
} 
the issue of death-qualification is hotly contested today, in large part because of the great disconnect between findings from social science on the prejudicial nature of capital-qualification and the practices currently being employed. In an age marked by ever-growing skepticism concerning the ability of the state to impose the death penalty in a fair manner, ${ }^{13}$ the debate over death-qualification can hardly be considered "an open-and-shut case." ${ }^{14}$ According to some researchers' estimations, ${ }^{15}$ the temperature of state cultures toward capital punishment has never been more conducive for introducing desperately needed reforms on a variety of issues. Similarly, the Supreme Court has carved out protections for particularly vulnerable populations within the past decade and a half, electing to exempt them from society's harshest punishment. ${ }^{16}$ The Court has traditionally ruled that evidence on the biasing effects of death-qualification is too flawed to establish a Sixth Amendment violation. ${ }^{17}$ Some believe, however, that the Court has been growing more receptive over time. ${ }^{18}$ Thus, it may be only a matter of time until the Court takes on a new case with capital juror qualification practices at its center. ${ }^{19}$ If the Court does elect to revisit jury qualification practices, however, there is no guarantee it will overturn previously established precedents. Indeed, given the wide latitude afforded to trial judges in making final decisions for juror exclusion, cautious optimism should be tempered with the knowledge that, historically, the Court has shown great deference to trial judges.

\section{Supreme Court Cases Addressing Capital Disqualification Procedures}

Death-qualification arose out of concerns that abolitionists would highjack trial proceedings as a form of protesting the possibility of death. The argument at the time was abolitionist jurors in the pre-Gregg v. Georgia ${ }^{20}$ era would nullify the jury by refusing to convict the defendant, despite being convinced beyond a reasonable doubt of the defendant's guilt. ${ }^{21}$ This was possible because the bifurcated trial design instituted by the Court in Gregg had not yet been established, and therefore a conviction was more closely associated with a death sentence. While the Court was concerned about rogue jurors imposing their will on the jury and making a mockery of court

\footnotetext{
${ }^{13}$ See Craig Haney \& Richards L. Wiener, Death is Different: An Editorial Introduction to the Theme Issue, 10 Psychol., PUB. PoL., \& L. 373 (2004).

${ }^{14}$ See Victoria Springer \& Camille B. Lalasz, Death-Qualified Jurors and the Assumption of Innocence: A Cognitive Dissonance Perspective on Conviction-Prone Verdicts. 51 Soc. SCI. J. 287, 289 (2014).

${ }^{15}$ See Charles S. Lanier \& James R. Acker, Capital Punishment, the Moratorium Movement, and Empirical Questions: Looking Beyond Innocence, Race, and Bad Lawyering in Death Penalty Cases. 10 PsYCHOL., PUB. PoL., \& L. 577, 603 (2004)("[T]he country-or at least many parts of it-stands poised at the threshold of potentially dramatic changes in its death penalty policies and practices.").

${ }^{16}$ Atkins v. Virginia, 536 U.S. 304 (2002), exempted intellectually disabled defendants from being sentenced to death or executed, and Roper v. Simmons, 543 U.S. 551 (2005), excluded juveniles from being sentenced to death or executed.

${ }^{17}$ See Brooke Butler \& Gary Moran, The Role of Death Qualification and Need for Cognition in Venirepersons' Evaluations of Expert Scientific Testimony in Capital Trials, 25 BEHAV. SCI. L. 561, 563 (2007).

${ }^{18}$ See Brooke Butler \& Gary Moran, The Impact of Death Qualification, Belief in a Just World, Legal Authoritarianism, and Locus of Control on Venirepersons' Evaluations of Aggravating and Mitigating Circumstances in Capital Trials, 25 BeHAV. SCI. L. 57, 67 (2007).

${ }^{19}$ Lockhart v. McCree, 476 U.S. 162 (1986).

20 Gregg v. Georgia, 428 U.S. 153 (1976).

${ }^{21}$ See Clark, supra note 5 , at 8.
} 
proceedings, the Court had ruled previously that after all efforts have been taken to prevent jury nullification, there is ultimately not much that can be done to prevent it. As long as a juror appears to be acting in good faith without having been informed of the practice by another party, jury nullification is legal, though discouraged. ${ }^{22}$

Table 1 presents an overview of important Court cases pertaining to death-qualification. In Witherspoon v. Illinois, ${ }^{23}$ Witherspoon's attorney objected to the exclusion of prospective jurors unwilling to impose the death penalty, arguing the remaining jurors were more likely to both convict and sentence the defendant to death. The Court disagreed, citing a lack of rigorous empirical research demonstrating death-qualified jurors were more likely to convict a defendant. Thus, the practice was declared constitutional. Prospective jurors who raised "general objections to the death penalty or expressed conscientious or religious scruples against its infliction," however, could not be disqualified. ${ }^{24}$ Witherspoon established two pathways to disqualification. The first disqualified any juror who would universally refuse to support a death sentence; the second disqualified any juror with personal convictions regarding the death penalty which would keep them from assessing the defendant's guilt based solely on the facts presented at trial. ${ }^{25}$ One year later, the Court addressed the case of a prospective juror struck from the jury because of a "fixed opinion against" the death penalty. ${ }^{26} \mathrm{Although}$ the justices deemed the issue outside of their control for other reasons, they hinted they would have affirmed Witherspoon as only disqualifying jurors who could not properly follow the law as a consequence of their personal convictions. In sum, any juror who could decide the case based on its own merits rather than on personal convictions was considered qualified regardless of whether the juror totally opposed the death penalty.

Almost a decade later, after the Court's institution of the bifurcated capital trial procedure in Gregg, ${ }^{27}$ the Court reiterated that Witherspoon ${ }^{28}$ required the disqualification of prospective jurors if they conceded that knowing the defendant could be sentenced to death would interfere with their decision to assess the defendant's guilt. ${ }^{29} \mathrm{~A}$ second important finding was that it was unconstitutional for states to restrict the number or type of mitigating factors jurors could consider when determining if the defendant deserved a sentence less than death. In Adam v. Texas the Court ruled that it was unconstitutional to disqualify jurors who would be "affected" by their death penalty views. ${ }^{30}$ The Court reasoned it is fine for jurors to be influenced by their personal convictions; it is only when these convictions preclude them from performing their duties as impartial judges of the facts or giving at least a minimum level of consideration to mitigating or aggravating factors that a defendant's Sixth Amendment right is violated.

22 Sparf v. United States, 156 U.S. 51 (1895).

${ }^{23}$ Witherspoon v. Illinois, 391 U.S. 510 (1968).

24 Id. at 522.

${ }^{25} / d$. at 522 n.21.

${ }^{26}$ Boulden v. Holman, 394 U.S. 478, 484 (1969).

27 See Gregg v. Georgia, 428 U.S. 153 (1976).

${ }^{28}$ See Witherspoon, 91 U.S. at 510.

${ }^{29}$ Lockett v. Ohio, 438 U.S. 586 (1978).

${ }^{30}$ Adams v. Texas, 448 U.S. 38, 50 (1980). 
Table 1: Leading U.S. Supreme Court Cases on Death-Qualification Standards

\begin{tabular}{|c|c|c|c|}
\hline Case & Issue & $\begin{array}{l}\text { Court } \\
\text { Ruling }\end{array}$ & Reason for Decision \\
\hline $\begin{array}{l}\text { Witherspoon v. Illinois, } \\
291 \text { U.S. } 510 \text { (1968) }\end{array}$ & $\begin{array}{l}\text { Does excluding jurors } \\
\text { ideologically opposed to the } \\
\text { death penalty violate a } \\
\text { defendant's right to trial by } \\
\text { 'impartial jury' according to the } \\
\text { 6th \& 14th Amendments? }\end{array}$ & Yes & $\begin{array}{l}\text { No evidence excluding jurors } \\
\text { universally opposed to death } \\
\text { penalty creates death-biased } \\
\text { jury. However, excluding jurors } \\
\text { ideologically opposed to the } \\
\text { death penalty does create a } \\
\text { death-biased jury. }\end{array}$ \\
\hline $\begin{array}{l}\text { Lockett v. Ohio, } 438 \\
\text { U.S. } 586 \text { (1978) }\end{array}$ & $\begin{array}{l}\text { Can jurors be excluded if they } \\
\text { indicate they would have a hard } \\
\text { time finding a defendant guilty if } \\
\text { he/she faced the death penalty? }\end{array}$ & Yes & $\begin{array}{l}\text { Jurors who are unable to follow } \\
\text { the law because of their } \\
\text { opposition to the death penalty } \\
\text { should be excluded. }\end{array}$ \\
\hline $\begin{array}{l}\text { Adams v. Texas, } 448 \\
\text { U.S. } 38 \text { (1980) }\end{array}$ & $\begin{array}{l}\text { Can jurors be excluded if they } \\
\text { admit they would be 'affected' } \\
\text { when answering a series of } \\
\text { mandatory questions which, if } \\
\text { answered in the affirmative, } \\
\text { would result in the defendant's } \\
\text { death? }\end{array}$ & No & $\begin{array}{l}\text { Jurors cannot be excluded as } \\
\text { long as they give at least } \\
\text { minimal consideration to both } \\
\text { mitigating and aggravating } \\
\text { circumstances. }\end{array}$ \\
\hline $\begin{array}{l}\text { Wainwright v. Witt, } 470 \\
\text { U.S. } 1039 \text { (1985) }\end{array}$ & $\begin{array}{l}\text { Can jurors not universally } \\
\text { opposed to the death penalty, } \\
\text { but who are strongly limited in } \\
\text { their ability to be objective at } \\
\text { trial, be excluded? }\end{array}$ & Yes & $\begin{array}{l}\text { Jurors who are 'substantially } \\
\text { impaired' in their ability to } \\
\text { follow the law because of their } \\
\text { opposition to the death penalty } \\
\text { should be excluded. }\end{array}$ \\
\hline $\begin{array}{l}\text { Lockhart v. McCree, } \\
476 \text { U.S. } 162 \text { (1986) }\end{array}$ & $\begin{array}{l}\text { Does excluding jurors strongly } \\
\text { limited in their ability to be } \\
\text { objective at trial violate a } \\
\text { defendant's right to trial by } \\
\text { 'impartial jury' according to the } \\
\text { 6th \& 14th Amendments? }\end{array}$ & No & $\begin{array}{l}\text { The methodology of existing } \\
\text { studies demonstrating death- } \\
\text { qualification produces death- } \\
\text { biased juries is too flawed to } \\
\text { conclude death-qualification } \\
\text { violates the 6th Amendment. }\end{array}$ \\
\hline $\begin{array}{l}\text { Morgan v. Illinois, } 504 \\
\text { U.S. } 719 \text { (1992) }\end{array}$ & $\begin{array}{l}\text { Can jurors universally opposed } \\
\text { to a punishment other than the } \\
\text { death penalty be excluded? }\end{array}$ & Yes & $\begin{array}{l}\text { Questioning during voir dire } \\
\text { needs to be thorough enough to } \\
\text { identify jurors universally } \\
\text { supportive of a death sentence. } \\
\text { Jurors must be able to follow } \\
\text { the law over their personal } \\
\text { convictions. }\end{array}$ \\
\hline $\begin{array}{l}\text { Uttecht v. Brown, } 551 \\
\text { U.S. } 1 \text { (2007) }\end{array}$ & $\begin{array}{l}\text { Are appellate courts, in the } \\
\text { absence of clear evidence of } \\
\text { wrongdoing, required to } \\
\text { operate under the assumption } \\
\text { that trial judges were right to } \\
\text { dismiss jurors? }\end{array}$ & Yes & $\begin{array}{l}\text { Trial judges have access to } \\
\text { information not contained } \\
\text { within court documents } \\
\text { because they are physically } \\
\text { present at the trial. }\end{array}$ \\
\hline
\end{tabular}


Wainwright $v$. Witt ${ }^{31}$ expanded the criteria for disqualification based on an interpretation of Witherspoon ${ }^{32}$ cited in Adams. This new standard allowed for disqualification when a juror's death penalty convictions threatened to "prevent or substantially impair the performance of his duties as a juror in accordance with his instructions and his oath." 33 The Court also found the burden of proof is on higher courts to establish the trial judge made a discernible error when disqualifying a prospective juror before they can overturn a death sentence. ${ }^{34}$ Following closely after this decision was Lockhart v. McCree, ${ }^{35}$ in which the Court again considered the matter of whether the deathqualification process produced biased jurors and violated a defendant's right to trial by impartial jury. Here, as before in Witherspoon, ${ }^{36}$ the Court justified upholding the constitutionality of the practice by citing an absence of sufficiently rigorous studies.

In Ross v. Oklahoma, ${ }^{37}$ the petitioner alleged his right to trial by impartial jury was violated by the judge's refusal to disqualify a prospective juror who intended to automatically vote for a death sentence if the defendant was convicted. The Court found a constitutional violation would have occurred if the juror had remained seated, but decided against the petitioner because his attorney had used a peremptory strike to remove the juror in question prior to the start of the guilt phase. The Court ruled a few years later in Morgan v. Illinois ${ }^{38}$ that prospective jurors need to be lifequalified as well - that is, jurors "who will automatically vote for the death penalty in every case," thereby "fail[ing] in good faith to consider the evidence of aggravating and mitigating circumstances as the instructions require" should be disqualified. ${ }^{39}$ According to some scholars, this case also decided that jurors who characterize a "particular mitigating factor" as never deserving of attention should be disqualified. ${ }^{40}$ Regardless of which interpretation is correct, this case demonstrates the term death-qualification is misleading. Because jurors must be willing to consider a death or life sentence in order to sit on a capital jury, this process can be more accurately described as capital juror disqualification. Finally, among other things, the Court confirmed in Uttecht $v$. Brown ${ }^{41}$ that it intends to abide by the criteria they outlined in Witt ${ }^{42}$ for juror disqualification, and the burden of proof rests on higher courts to demonstrate the trial judge erred in disqualifying a prospective juror. Furthermore, in making determinations regarding the exclusion of a prospective juror, the trial judge could consider "the demeanor of the juror" 43 in addition to their voir dire responses.

\footnotetext{
${ }^{31}$ See Wainwright v. Witt, 469 U.S. 412 (1985).

32 See Witherspoon, 91 U.S. at 510.

${ }^{33}$ See Wainwright, 469 U.S. at 420 (quoting Adams v. Texas, 448 U.S. 38, 45 (1980)).

${ }^{34}$ See Wainwright, 469 U.S. at 431.

${ }^{35}$ See Lockhart v. McCree, 476 U.S. 162 (1986).

${ }^{36}$ See Witherspoon, 91 U.S. at 510.

${ }^{37}$ Ross v. Oklahoma, 487 U.S. 81 (1988).

${ }^{38}$ Morgan v. Illinois, 504 U.S. 719 (1992).

39 ld. at 729.

${ }^{40}$ See Blume, Johnson, \& Threlkeld supra, note 2, at 1218.

41 Uttecht v. Brown, 551 U.S. 1 (2007).

${ }^{42}$ See Wainwright v. Witt, 469 U.S. 412 (1985).

${ }^{43}$ See Uttecht, 551 U.S. at 9.
} 


\section{Review and Analysis}

\section{A. A Case for State Statutes Over Case Law}

This research examines state statutes. Although case laws exist which help determine capital juror disqualification processes in various states, ${ }^{44}$ the number of states which retain the death penalty in at least name is too great to make a search of all state court cases related to capital juror disqualification practical. A second reason is that fundamental differences exist between state statutes and case law. For example, state statutes are enacted by legislators elected to represent the people, and therefore are symbolic of a public commitment to certain values. In contrast, judge-made laws are generally a product of judicial interpretation of existing law.

One scholar defines case law as "an evolving process that never settles on any immutable rule ... [but rather] incorporates all different judicial points of view, each tending to smooth out the rough edges of another." 45 The imagery evoked is like a rock being tumbled in the ocean slowly over time until finally it emerges smooth and polished. Although statutes are less flexible than case law, case law is less immediate in effect than state statutes. What case law gains in flexibility it loses in immediacy, since courts can only set a precedent if they first hear a case on the statute in question. Additionally, courts are charged with interpreting the laws which exist, and cannot create new laws to address aspects of capital juror disqualification that were never touched on in the original statute. This is significant because, while many states have addressed inadequacies of their original statute through case law, few researchers would argue that these changes have sufficiently addressed all deficiencies in capital juror disqualification criteria. Despite the validity of statutes being modified through case law, one scholar labels the current disqualification process "woefully ineffective." ${ }^{46}$ When inadequate statutes are in place, case law addresses and corrects those inadequacies even if the people do not wish to act. If, however, these changes to a state statute are never implemented into the legislation, they may be eroded over time by judges who have decided those precedents should no longer be binding, or are less compelling than other precedents which demand a different interpretation of the law.

As others before have recognized, states need not wait for court precedents before correcting injustices associated with the current capital juror disqualification process. Instead, they should set an example for the courts to follow. ${ }^{47}$ This is particularly notable because the United States Supreme Court has a tradition of using the number of states which engage in a particular practice as a gauge for determining if that practice is cruel or unusual. ${ }^{48}$ State statutes, therefore, are preferable. They can be viewed as symbolic of the people's commitment to particular values. Statutes can be enacted more quickly, are generally more permanent, and appropriately place the burden of lawmaking on legislators as representatives of the people rather than on the courts. This

\footnotetext{
${ }^{44}$ See Bruce J. Winik, Witherspoon in Florida: Reflections on the Challenge for Cause of Jurors in Capital Cases in a State in Which the Judge Makes the Sentencing Decision, 37 U. MIAMI L. REV. 825 (1983) (examining the effect of death-qualification in Florida and noting several state court cases that govern the process in that state).

45 See Giacomo A. M. Ponzetto \& Patricio A. Fernandez, Case Law Versus Statute Law: An Evolutionary Comparison, 37 J. LEG. STUD. 379, 386 (2008).

${ }^{46}$ See Bloom, Johnson, \& Threlkeld, supra note 2, at 1211.

47 See Kyle Wackenheim, Note, State v. Fry: Reconsidering Death-Qualification in New Mexico Capital Trials, 38 N. M. L. REV. 627, 652 (2008).

${ }^{48}$ Roper v. Simmons, 543 U.S. 551, 557 (2005) (citing Trop v. Dulles, 356 U. S. 86, 100-101 (1958)).
} 
allows states to influence the likelihood of future practices being interpreted as cruel and unusual by the Supreme Court.

\section{B. Direct and Indirect Criteria for Disqualification}

Thirty-one states still have a law permitting the use of the death penalty. Of these, fifteen states have temporarily halted executions. Among states with the death penalty, sixteen have a statute that directly defines the criteria necessary for disqualification of a prospective juror in a capital trial (see infra, Table 2).

Of the other fifteen states, twelve have statutes that are not specific to capital trials, but nonetheless have some bearing on capital juror disqualification. Only Kentucky, Oregon, and Pennsylvania lack statutes that either directly or indirectly spell out the circumstances under which capital jurors can be disqualified. In these three instances, it is likely case law governs the details of capital juror disqualification. It is interesting to note that Oregon is the only state among these three to list specific challenges for cause, but not include a challenge that could be considered to even broadly address capital juror disqualification criteria.

A lot of variance exists between states which directly address capital juror disqualification and those that only address it through challenges for cause, which are also applicable to non-capital trials. For example, "[w]hen the offense is punishable with death," Arkansas permits disqualification if a prospective juror appears to be "entertaining ... such conscious opinions as would preclude him from finding the defendant guilty." 49 In contrast, Virginia, which does not specifically address the issue of capital juror disqualification, allows a prospective juror who "has any interest in the case, or has expressed or formed any opinion, or is sensible of any bias or prejudice therein" to be disqualified "if it shall appear to the court that the juror does not stand indifferent in the cause." ${ }^{50}$ Washington, another state which neglects directly addressing capital juror disqualification, allows prospective jurors to be excluded "[f]or the existence of a state of mind ... in reference to the action, or to either party, which satisfies the court that the challenged person cannot try the issue impartially and without prejudice to the substantial rights of the party challenging." ${ }^{51}$

Among the twelve states that have statutes aimed at challenges for cause not specific to capital trials (indirect capital juror disqualification criteria), North Carolina is concerned with jurors who cannot follow the law when delivering a verdict as a consequence of "matter of conscience." 52 New Hampshire, South Carolina, and Virginia all use slightly different terminology to address a juror who is "prejudiced to any degree." ${ }^{53}$ Missouri allows for the disqualification of a juror whose "opinions or beliefs" 54 prevent them from performing their duty as a juror according to the law. Kansas, South Dakota, Tennessee, and Washington all reference a juror who possesses a "state of mind" 55 that would inhibit their ability to judge impartially. Arizona and Nevada allude to both a

${ }^{49}$ Ark. Code Ann. § 16-33-304(b)(2)(vii) (2015).

${ }^{50}$ VA. CODE ANN. § 8.01-358 (2015).

51 WASH. REV. CODE $\S 4.44 .170(2)(2015)$.

52 N.C. Gen. StAT. § 15A-1212(8) (2015).

53 N.H. Rev. Stat. Ann. § 500-A: 12(I)(f) (2015). See S.C. Code Ann. § 14-7-1020 (2015); VA. Code Ann. § 8.01358 (2015).

54 Mo. Rev. Stat. $\$ 494.470(2)(2011)$.

55 Kan. Stat. Ann. § 22-3410(2)(i) (2014); S.D. Codified Laws § 23A-20-13.1(21) (2015); Tenn. Code Ann. § 22-1105 (2014); WASH. Rev. CODE § 4.44.170(2) (2015). 
juror's opinions or beliefs and their state of mind.$^{56}$ As previously discussed, Oregon does not provide any criteria for disqualification applicable to jurors' death penalty views in capital trials.

Table 2: Death-Qualification Provisions in States With the Death Penalty

\begin{tabular}{|c|c|c|}
\hline State & Defines Death-Qualification? & Lists Challenges for Cause? \\
\hline Alabama & Directly & Yes \\
\hline Arizona & Indirectly & Yes \\
\hline Arkansas & Directly & Yes \\
\hline California & Directly & Yes \\
\hline Colorado & Directly & Yes \\
\hline Delaware & Directly & No \\
\hline Florida & Directly & Yes \\
\hline Georgia & Directly & Yes \\
\hline Idaho & Directly & Yes \\
\hline Indiana & Directly & Yes \\
\hline Kansas & Indirectly & Yes \\
\hline Kentucky & No & No \\
\hline Louisiana & Directly & Yes \\
\hline Mississippi & Indirectly & Yes \\
\hline Missouri & Indirectly & Yes \\
\hline Montana & Directly & Yes \\
\hline Nevada & Indirectly & Yes \\
\hline New Hampshire & Indirectly & Yes \\
\hline North Carolina & Indirectly & Yes \\
\hline Ohio & Directly & Yes \\
\hline Oklahoma & Directly & Yes \\
\hline Oregon & No & Yes \\
\hline Pennsylvania & No & No \\
\hline South Carolina & Indirectly & Yes \\
\hline South Dakota & Indirectly & Yes \\
\hline Tennessee & Indirectly & Yes \\
\hline Texas & Directly & Yes \\
\hline Utah & Directly & Yes \\
\hline Virginia & Indirectly & Yes \\
\hline Washington & Indirectly & Yes \\
\hline Wyoming & Directly & Yes \\
\hline
\end{tabular}

NOTE: While this article was in press, Delaware abolished its death penalty.

\section{Witherspoon and Witt Standards for Disqualification}

Under the Witt criteria, the Supreme Court broadened capital juror disqualification criteriawhich previously only dismissed prospective jurors who would "unambiguously" and

5616 A.R.S. Rules of Civil Procedure, Rule 47(c)(4-5); NeV. ReV. StAT. § 16.050(1)(g) (2010). 
"automatically" 57 refuse to impose a death sentence as ruled in Witherspoon-to also exclude jurors whose personal convictions regarding the death penalty would "prevent or substantially impair" 58 them from determining the case according to the law. Of the sixteen states that directly address capital juror disqualification, only Louisiana, Utah, and Wyoming use Witt terminology in their statutes (see infra, Table 3).

Wyoming copies the Witt standard almost word for word, ${ }^{59}$ while both Louisiana and Utah include the key phrase "prevent or substantially impair."60 In addition to the Witt standard, Louisiana's statute allows for disqualification in cases where the juror "would automatically vote against the imposition of capital punishment without regard to any evidence that might be developed at the trial of the case before him [the juror]" or possesses an "attitude toward the death penalty [that] would prevent him from making an impartial decision as to the defendant's guilt." 61

The remaining thirteen states have statutes that utilize language more consistent with Witherspoon disqualification criteria. For example, Alabama allows the disqualification of any capital juror who "would refuse to impose the death penalty regardless of the evidence produced." 62 Such a statute fails to address prospective jurors who may only be "substantially impaired"63 in their ability to adhere to the law and set aside their personal conviction. Similarly, prospective jurors in Colorado can be disqualified if they "state that they would not be able to consider and impose the death penalty under any circumstances because of religious, ethical, or moral scruples against the death penalty." ${ }^{14}$

\section{Life-Qualification}

Although nothing about Witherspoon or Witt suggests they were only meant to address disqualification criteria for jurors opposed to the death penalty, the Court ruled in Morgan that any juror "who will automatically vote for the death penalty in every case" ${ }^{65}$ should be disqualified. Over two decades after the Court's decision, no state has yet to adopt the protections against death granted in Morgan by explicitly stating capital jurors who will always support a death sentence should be disqualified. Even worse, fourteen of the sixteen states use language which makes it clear the disqualification criteria applies solely to jurors opposed to capital punishment. Only Utah and Wyoming employ neutral language that does not specify which direction a prospective juror's bias must lie in before they are eligible for disqualification. As a comparison, Utah's statute addresses "juror's views on capital punishment," ${ }^{66}$ whereas Oklahoma's statute references jurors who are "entertaining of such conscientious opinions as would preclude his finding the defendant guilty. ${ }^{167}$ Most damning, however, is the complete lack of any state statute

57 See Witherspoon v. Illinois, 391 U.S. 510, 516 n.9 (1968).

${ }^{58}$ See Wainwright v. Witt, 469 U.S. 412 (1985) (quoting Adams v. Texas, 448 U.S. 38, 45 (1980)).

59 Wro. StAT. AnN. § 7-11-105(a)(iii) (2015).

${ }^{60}$ La. Code Crim. Proc. Ann. art. 798(2)(b) (2011); UtAh R. Crim. P. 18(e)(10).

${ }^{61}$ LA. Code Crim. Proc. AnN. art. 798(2)(b) (2011).

${ }^{62}$ ALA. CODE § 12-16-152 (2015).

${ }^{63}$ See Witt, 469 U.S. at 412 (quoting Adams, 448 U.S. at 45).

${ }^{64}$ Colo. Rev. Stat. 13-71-105 (2015).

${ }^{65}$ Morgan v. Illinois, 504 U.S. 719 (1992).

66 UTAH R. CRIM. P. 18(e)(10).

67 OKLA. STAT. tit. $22 \S 660$ (8) (2014). 
explicitly stating prospective jurors who favor the use of the death penalty in a way that merely "substantially impair[s]" rather than outright "prevent[s]" 68 them from following the law should be disqualified.

Table 3: Criteria Used for Juror Disqualification in States with Death Qualification Provisions

\begin{tabular}{|c|c|c|c|c|}
\hline State & $\begin{array}{l}\text { Witherspoon } \\
\text { Standard? }\end{array}$ & $\begin{array}{l}\text { Witherspoon } \\
\text { Standard? }\end{array}$ & Witt Standard? & $\begin{array}{l}\text { Pro-Life Witt } \\
\text { Standard? }\end{array}$ \\
\hline Alabama & Yes & No & No & No \\
\hline Arkansas & Yes & No & No & No \\
\hline California & Yes & No & No & No \\
\hline Colorado & Yes & No & No & No \\
\hline Delaware & Yes & No & No & No \\
\hline Florida & Yes & No & No & No \\
\hline Georgia & No & No & No & No \\
\hline Idaho & Yes & No & No & No \\
\hline Indiana & Yes & No & No & No \\
\hline Louisiana & Yes & Yes & No & No \\
\hline Montana & Yes & No & No & No \\
\hline Ohio & Yes & No & No & No \\
\hline Oklahoma & Yes & No & No & No \\
\hline Texas & No & No & No & No \\
\hline Utah & Yes & Yes & Indirectly & Indirectly \\
\hline Wyoming & Yes & Yes & Indirectly & Indirectly \\
\hline
\end{tabular}

NOTE: While this article was in press, Delaware abolished its death penalty.

Although some of the fourteen states likely applied Morgan's protections through case law rather than amending the statutes themselves, they have made a point of specifically addressing only pro-defense biases in their written code. This suggests states are more committed to suppressing the voice of jurors who wish to protest the state's use of capital punishment than they are to protecting the accused's right to trial by impartial jury. The effectiveness of this strategy can be seen in the social science literature, which has firmly established death-qualified jurors as both more likely to convict the defendant and to return a death sentence. ${ }^{69}$ Such jurors also score higher on a whole host of secondary measures known to increase the likelihood of condemning a defendant to death, ${ }^{70}$ and are more likely to consider aggravating circumstances to have been

\footnotetext{
68 Wainwright v. Witt, 469 U.S. 412, 424 (1985).

${ }^{69}$ See Brooke Butler, The Role of Death Qualification in Jurors' Susceptibility to Pretrial Publicity, $37 \mathrm{~J}$. Applied. Soc. Psychol. 115, 116 (2007); see also 4 Joseph W. Filkins, Christine M. Smith, \& R. Scott Tindale, A Meta-Analytic/Computer Simulation Approach, in THEORY AND RESEARCH ON SMALL Groups 153, 175 (R. Scott Tindale et al. eds., 2002); Jeremy A. Blumenthal, Implicit Theories and Capital Sentencing: An Experimental Study (1st Annual Conf. on Empirical Legal Stud. Paper, Working Draft, June 2006), http://ssrn.com/abstract=909603.

${ }^{70}$ See Brooke Butler \& Gary Moran, The Role of Death Qualification and Need for Cognition in Venirepersons' Evaluations of Expert Scientific Testimony in Capital Trials, 25 BeHAV. SCI. LAW 561 (2007).
} 
present and mitigating factors inconsequential. ${ }^{71}$ Even if case law eventually evolved to protect rights guaranteed by the Supreme Court, states were clearly not concerned about what might happen to defendants tried in the intermediate period after Morgan but before case law evolved.

Table 4: Other Dimensions of Juror Disqualification in States With Death Qualification Provisions

\begin{tabular}{|c|c|c|c|c|}
\hline State & $\begin{array}{l}\text { Excludes Witt- } \\
\text { Includables? }\end{array}$ & $\begin{array}{l}\text { Mandatory Voir } \\
\text { Dire Questions? }\end{array}$ & $\begin{array}{l}\text { Specifies Oral } \\
\text { vs. Written } \\
\text { Questioning? }\end{array}$ & $\begin{array}{l}\text { Excluded if } \\
\text { Personal } \\
\text { Convictions } \\
\text { Influence Guilt } \\
\text { or Sentencing } \\
\text { Phase? }\end{array}$ \\
\hline Alabama & No & No & No & Sentence \\
\hline Arkansas & No & No & No & Guilt \\
\hline California & No & No & No & Guilt \\
\hline Colorado & No & No & No & Sentence \\
\hline Delaware & No & Yes & No & Guilt \\
\hline Florida & No & No & No & Guilt \\
\hline Georgia & Yes & Yes & No & $\mathrm{N} / \mathrm{A}$ \\
\hline Idaho & No & No & No & Guilt \\
\hline Indiana & No & No & No & Sentence \\
\hline Louisiana & No & No & No & Both \\
\hline Montana & No & No & No & Guilt \\
\hline Ohio & No & No & No & Sentence \\
\hline Oklahoma & No & No & No & Guilt \\
\hline Texas & Yes & No & No & Sentence \\
\hline Utah & No & No & No & $\mathrm{N} / \mathrm{A}$ \\
\hline Wyoming & No & No & No & $\mathrm{N} / \mathrm{A}$ \\
\hline
\end{tabular}

NOTE: While this article was in press, Delaware abolished its death penalty.

\section{Other Issues Related to Disqualification}

\section{A. Disqualifying Witt-Includables}

At least two of the sixteen states which directly address capital juror disqualification criteria endorse standards that would exclude jurors who would be considered death-qualified under the Court's Witt standard (see infra, Table 4).

Georgia requires prospective jurors to answer the question: "'Are you conscientiously opposed to capital punishment?' If the juror answers this question in the negative, he shall be held to be a competent juror. ${ }^{172}$ Similarly, Texas allows for the disqualification of a juror who "has conscientious scruples in regard to the infliction of the punishment of death for crime, in a capital case. ${ }^{173}$ Both states make no reference to a prospective juror's ability to follow the law despite

${ }^{71}$ See Butler \& Moran, supra note 3, at 175.

72 GA. COdE ANn. § 15-12-164(a)(4) (2015).

73 Tex. Code Crim. Proc. Ann. art. 35.16(b)(1) (West 2013). 
their personal convictions. The Court in Witt specifically stated a juror can only be disqualified if their personal convictions regarding the death penalty "prevent or substantially impair the performance of his duties as a juror in accordance with his instructions and his oath. ${ }^{174}$ Because neither the Georgia nor Texas statute allows for the possibility of a juror who is ardently opposed to capital punishment in all circumstances but still intends to faithfully carry out their duties as a juror to the best of their ability, these statutes give the impression that simply expressing categorical opposition to the death penalty is adequate grounds for disqualification. This is certainly not the case, however, as the Court notes "jurors who, though opposed to capital punishment, will nevertheless conscientiously apply the law to the facts adduced at trial" 75 should be retained. In contrast to Georgia and Texas, Ohio stands out as the only state to clarify "[a] prospective juror's conscientious or religious opposition to the death penalty in and of itself is not grounds for a challenge for cause." ${ }^{176}$

\section{B. Mandatory Voir Dire Questions}

At the center of the inadequacies in the current capital juror disqualification criteria is the reality that two prospective jurors who give virtually identical answers during voir dire questioning may or may not be treated similarly regarding disqualification. This holds true regardless of whether both jurors are part of the same trial, from the same jurisdiction, or from separate jurisdictions within the same state. Such occurred in Davis v. Ayala, ${ }^{77}$ where the defense alleged prospective jurors were disqualified for expressing similar views held by jurors who remained seated. One potential way to ensure prospective jurors with similar views are treated uniformly is to require all jurors to answer a "minimum mandatory" threshold of questions aimed at vetting jurors to the same degree. ${ }^{78}$ While the Court has been clear that "[t]he Constitution ... does not dictate a catechism for voir dire," 79 the practice is not inherently forbidden, and promises to provide better opportunities to accurately probe prospective jurors' death penalty views. In other words, the Court exists to establish the minimum level of rights a state must honor regarding the treatment of its people, but this minimum should by no means serve as the measure for determining whether capital juror disqualification criteria are sufficient.

Toward this end, the sixteen states which specifically address capital juror disqualification criteria were analyzed to determine the presence of mandatory questions during voir dire. Only Delaware and Georgia possess statutes that include mandatory questions. Georgia requires jurors to answer if they are "conscientiously opposed to capital punishment." 80 Jurors who answer 'yes' are disqualified, while jurors who answer 'no' are allowed to remain seated. Delaware employs a more rigorous questioning procedure, and has jurors first indicate if they have,

[F]ormed or expressed any opinion in regard to the guilt or innocence of the prisoner at the bar. If the answer is in the negative, the juror shall be sworn as a juror in the case, unless the juror has conscientious scruples against finding a

\footnotetext{
${ }^{74}$ See Wainwright v. Witt, 469 U.S. 412 (1985).

${ }^{75}$ See id. at 421.

76 Ohio Rev. Code Ann. § 2945.25(C) (West 2015).

77 Davis v. Ayala, 135 S. Ct. 2187, 2201 (2015).

${ }^{78}$ See Jesse Nason, Mandatory Voir Dire Questions in Capital Cases: A Potential Solution to the Biases of Death Qualification, 10 ROgeR WILLIAMs U. L. ReV. 211, 213 (2004).

${ }^{79}$ See Morgan v. Illinois, 504 U.S. 719, 729 (1992).

${ }^{80}$ GA. COdE ANN. § 15-12-164(a)(4)
} 
verdict of guilty in a case where the punishment is death, even if the evidence should so warrant.... If the juror's answer to the question be in the affirmative, to the satisfaction of the court, that the juror feels able, notwithstanding such an opinion, to render an impartial verdict upon the law and the evidence, in which event the juror shall be a competent juror, if not otherwise disqualified, challenged or excused. ${ }^{81}$

\section{Oral vs. Written Presentation of Questions}

Regarding the method of presenting capital juror disqualification questions-whether in written or oral form-one scholar recommends using written questionnaires administered "outside the courtroom" in order to avoid imposing on the court's limited time. ${ }^{82}$ Alternatively, some scholars call for a "far more detailed and probative-inquiry" 83 during voir dire, which would appear better suited for oral delivery. Possibly because of this disagreement over which methods are most desirable, or out of recognition that some built in flexibility is preferable, none of the sixteen states with capital-specific juror disqualification criteria address the form questions should be presented in.

\section{Guilt or Sentence Phase Bias}

In Witt, the Court determined "the tests with respect to sentencing and guilt, originally in two prongs, have been merged." 84 Previously in Witherspoon, ${ }^{85}$ before the bifurcated trial procedure had been established, ${ }^{86}$ a prospective juror could be disqualified for being biased either when assessing the defendant's guilt, or when determining the magnitude of the punishment deserved. Currently, the Court employs a more holistic approach where trial judges must determine whether, overall, a prospective juror's views toward capital punishment will "prevent or substantially impair" 87 their ability to follow the law despite strong personal convictions regarding the state's use of the death penalty (either for or against the practice).

Among the sixteen states with specific capital juror disqualification criteria, five (Alabama, Colorado, Indiana, Ohio, and Texas) specify prospective jurors' death penalty views are grounds for disqualification if they will prevent the juror from following the law when determining the proper sentence. Another seven (Arkansas, Colorado, Delaware, Florida, Idaho, Montana, and Oklahoma) are concerned with death penalty biases that might influence whether a prospective juror can follow the law when assessing the defendant's innocence or guilt. Three more (Georgia, Utah, and Wyoming) fail to identify a particular stage of trial when capital punishments biases are problematic. The final state's (Louisiana) statute is exemplary in this regard because it most closely resembles the Court's ruling in Witt-that death penalty biases are grounds for disqualification if a prospective juror cannot or will not follow the law during either the guilt or sentencing phase of a capital trial.

81 Del. Code. Ann. tit. 11, § 3301 (2015).

82 See Vida B. Johnson, Presumed Fair? Voir Dire on the Fundamentals of Our Criminal Justice System, 45 Seton Hall L. Rev. 545, 578 (2015).

${ }^{83}$ See Blume, Johnson, \& Thelkeld, supra note 2, at 1258.

${ }^{84}$ See Wainwright v. Witt, 469 U.S. 412, 421 (1985).

85 See Witherspoon v. Illinois, 391 U.S. 510 (1968).

${ }^{86}$ See Lockhart v. McCree, 476 U.S. 162, 165 (1986).

${ }^{87}$ See Witt, 469 U.S. 424. 
Indiana's statute allows for the disqualification of any "person [who] entertains such conscientious opinions as would preclude the person from recommending that the death penalty be imposed." 88 Idaho, on the other hand, lists grounds for disqualification as "the entertaining of such conscientious opinions as would preclude his finding the defendant guilty; in which case he must neither be permitted nor compelled to serve as a juror." 89 Prospective capital jurors in Louisiana can be disqualified if they "would automatically vote against the imposition of capital punishment without regard to any evidence that might be developed at the trial of the case before [them]" or their "attitude toward the death penalty would prevent [them] from making an impartial decision as to the defendant's guilt." 90

\section{Proposed Solutions}

\section{A. Abolition of Capital Qualified Juries}

Several scholars have called for the outright abolition of capital juror disqualification practices and a return to the inclusion of jurors biased in favor of and against the death penalty. ${ }^{91} \mathrm{~A}$ particularly compelling argument for abolition is the systematic exclusion of certain categories of individuals from capital juries, ${ }^{92}$ which may violate the fair cross-section requirement of the Sixth Amendment. At least one scholar labels capital trials "ideal settings for contemporary racism to flourish." ${ }^{93}$ The Court, however, upheld the constitutionality of death-qualification in the face of this very contention in Lockhart. ${ }^{94}$ Other scholars support abolishing capital juror qualification because the process itself has been identified as encouraging prospective jurors to support a conviction and subsequent death sentence. ${ }^{95}$ While the Court "reject[s] the argument that the very process of questioning prospective jurors at voir dire about their views of the death penalty violates the Constitution," 96 it is still possible for states to revise their statutes by changing the content of capital juror disqualification questions and the manner in which they are asked. As scholars have recognized, states "have a legitimate interest" ${ }^{97}$ in providing defendants a trial by impartial jury, and it is "apparent" 98 capital juror disqualification is the best process for screening

88 IND. CODE § 35-37-1-5(a)(1) (2015).

${ }^{89}$ IDAHO CODE § 19-2020(9) (2005).

90 See Witherspoon, 391 U.S. at 522 n.21.

91 See Butler \& Moran, supra note 17; see also Clark, supra note 5; Jane Tucker, An Alternative to DeathQualification: The Nonunanimous Penalty Jury (2012) (unpublished Yale Law School Legal Scholarship), http://digitalcommons.law.yale.edu/student_papers/118.

${ }^{22}$ See Alicia Summers, R. David Hayward, \& Monica K. Miller, Death Qualification as Systematic Exclusion of Jurors with Certain Religious and Other Characteristics, 40 J. APPL. Soc. Psy. 3218 (2010); see also Brooke Butler, The Role of Death Qualification in Capital Trials Involving Juvenile Defendants, 37 J. APPL. Soc. PsY. 549 (2007); UTAH R. CRIM. P. 18(e)(10).

${ }^{93}$ See Mona Lynch \& Craig Haney, Mapping the Racial Bias of the White Male Capital Juror: Jury Composition and the 'Empathetic Divide', 45 LAW \& Soc'Y REV. 69, 74 (2011).

${ }^{94}$ See Butler \& Moran, supra note 18.

${ }^{95}$ See Blume, Johnson, \& Threlkeld, supra note 2, at 1231; see also Craig Haney, On the Selection of Capital Juries, 8 LaW \& Human BeHAV. 121 (1984).

${ }^{96}$ See Butler \& Moran, supra note 18 , at 170 n.7.

97 See Butler \& Moran, supra note 3, at 183.

${ }^{98}$ See Richard Salgado, Tribunals Organized to Convict: Searching for a Lesser Evil in the Capital Juror DeathQualification Process in United States v. Green, 2005 BYU L. REV. 519, 537. 
out substantially biased jurors. Calls to abandon capital juror disqualification, therefore, are misguided. A more reasonable solution for correcting biases inherent in the disqualification process itself is to pay careful attention to the order in which questions are asked and the balance between the number of questions addressing pro-life versus pro-death biases. It is also important to restructure the wording of questions to include neutral language. ${ }^{99}$

A third reason some scholars support doing away with capital juror disqualification is a concern that judges restrict the amount of time spent on voir dire questioning in order to avoid overburdening the court's time and money. ${ }^{100}$ The problem with this heightened concentration on efficiency is that "very few protections for the rights of the accused are calculated to expedite criminal proceedings." ${ }^{101}$ One scholar identified a specific subtype of death-biased juror-one willing to consider a sentence other than death, but only for offenses ineligible for death in the first place-who can only be discovered through lengthy oral interrogation by the defense. ${ }^{102}$ For this reason, some scholars consider it important for the defense and prosecution, rather than the judge, to explore prospective jurors' death penalty views at leisure. Such a process would likely consume more of the court's resources, but this concern is overshadowed by the need to secure the defendant a trial by impartial jury. ${ }^{103}$

\section{B. Modifying Disqualifying Procedures}

Scholars who do not advocate complete abolition are split over how best to improve capital juror disqualification procedures. Some recommend using separate juries for the guilt and sentencing phases, ${ }^{104}$ while others want to continue employing a single jury and capital-qualifying jurors during voir dire, but wait until the start of the sentencing phase to reveal the results and disqualify the appropriate jurors from participating in the sentencing phase. ${ }^{105}$ Both fall short as solutions, however, as the Court has "upheld against constitutional attack the Georgia capital sentencing plan which provided that the same jury must sit in both phases of a bifurcated capital murder trial." ${ }^{106}$ It is possible, of course, that the Court could reverse their decision on this issue. Some may even interpret the recent Court ruling striking down Florida's capital punishment system, prohibiting judges from overruling juries' recommendations, as supporting this view. ${ }^{107}$ The difference between this ruling and Georgia's post-Furman capital punishment system, however, is that Florida's system was an abnormality relative to others states' systems, whereas all death penalty states currently employ a single jury for both phases of a capital punishment trial. Similarly, the second proposal fails to address the issue of death-qualified jurors sentencing defendants to death more often than disqualified jurors. ${ }^{108}$ The second approach also ignores the

\footnotetext{
${ }^{99}$ See Blume, Johnson, \& Threlkeld, supra note 2, at 1250-1251.

100 See Johnson, supra note 82, at 564.

${ }^{101}$ See Blume, Johnson, \& Threlkeld, supra note 2, at 1239.

102 See Marla Sandys \& Adam Trahan, Life Qualification, Automatic Death Penalty Voter Status, and Juror Decision Making in Capital Cases, 29 JUSTICE SYST. J. 385, 393 (2008).

${ }^{103}$ See Johnson, supra note 82, at 565-566.

104 See Sam Kamin \& Jeffrey J. Pokorak, Death-Qualification and True Bifurcation: Building on the Massachusetts Governor's Council's Work, 80 InD. L. J. 131 (2005).

${ }^{105}$ See Salgado, supra note 98, at 519.

106 See Butler \& Moran, supra note 18, at 180.

107 Hurst v. Florida, 136 S. Ct. 616 (2016).

${ }^{108}$ See Butler, supra note 69; Filkins, Smith, \& Tindale, supra note 69.
} 
original reason death-qualification was conceived: to prevent abolitionists from refusing to find a defendant guilty in cases where death is a possible outcome. ${ }^{109}$

At least one scholar has called for using implicit association tests to identify biases rather than the current Witt disqualification criteria. ${ }^{110}$ In order to screen out prospective jurors whose support for the death penalty would severely interfere with their ability to perform their duties as juror, yet another scholar suggested the defense ask jurors biased toward the prosecution if they would devote time and thought to the relevance of specific mitigating factors in determining the appropriate sentence. ${ }^{111}$ Finally, as previously discussed, some scholars believe a "minimum mandatory" threshold of questions asked of every prospective juror would uncover damning biases not brought to light by inadequate questioning. ${ }^{112}$ This additional questioning should be headed by the defense and prosecution, because they have the best chance of eliciting meaningful answers from jurors. ${ }^{113}$

\section{The Need for an Exploratory Statute}

\section{A. Justification}

Taken together, research suggests the need for a statute which should: (1) contain a minimum threshold of predetermined questions to be asked of all prospective jurors in order to provide standardization; ${ }^{114}$ (2) contain questions utilizing a two-step process to first determine if a prospective juror holds strong death penalty views, then assess whether these pro-death or prolife convictions would greatly diminish their ability to follow the law; ${ }^{115}(3)$ have questions using neutral language and require them to be presented in a non-biasing sequence; ${ }^{116}$ (4) structure questions to elicit yes or no answers to ensure clarity; ${ }^{117}$ (5) allow the defense and prosecution to follow up with oral questions until each prospective juror's answers can be properly classified as affirmative or negative; ${ }^{118}(6)$ require all prospective jurors to answer questions specific to both death penalty support and capital punishment opposition biases; ${ }^{119}$ and (7) allow the minimum threshold questions to be presented in either oral or written form. ${ }^{120}$

This article proposes an exploratory statute with mandatory minimum questions built into state law. In proposing such a statute, it should be clear what the article is and is not proposing. Social policies should always be empirically driven, and doubly so when individuals' lives hang in the balance. Thus, we are proposing an exploratory statute for the scholarly community to test

\footnotetext{
109 See Wainwright v. Witt, 469 U.S. 412 (1985).

${ }^{110}$ See Tanner C. Johnson, Comment, The Biasing Effect of Death Qualification: How Juror Attitudes Toward Capital Punishment Affect Conviction and Trial Proceedings, 7 Colum. Undergraduate L. Rev. 71, 84 (2014).

${ }^{111}$ See Blume, Johnson, \& Threlkeld, supra note 2, at 1259; see also Susan D. Rozelle, The Utility of Witt: Understanding the Language of Death Qualification, 54 BAYLOR L. REV. 677, 688 (2002).

112 See Nason, supra note 75.

${ }^{113}$ See Johnson, supra note 82 at 565.

${ }^{114}$ See Nason, supra note 78.

115 See Sandys \& Trahan, supra note 102.

${ }^{116}$ See Blume, Johnson, \& Threlkeld, supra note 2, at 1250-1251.

117 See Butler, supra note, 69, at 118; Del. Code. AnN. tit. 11, § 3301 (2015).

118 See Blume, Johnson, \& Threlkeld, supra note 83; Sandys \& Trahan, supra note 102.

${ }^{119}$ See Nason, supra note 78.

${ }^{120}$ See Blume, Johnson, \& Threlkeld, supra note 2, at 1254; Johnson, supra note 82, at 564.
} 
according to the scientific method-a statute which, if demonstrated effective at producing capital juries more representative of the community at large rather than just the pro-death community, states could benefit from implementing. Until and unless sufficient empirical evidence has been amassed to suggest the statute's effectiveness, however, we strongly discourage states from blindly implementing this or any other policy without a proper understanding of the associated consequences. In creating the proposed mandatory questions, special attention was given to the Colorado method for voir dire ${ }^{121}$ and the questions' readability. As far as possible, we tried to limit the mandatory questions to an eighth grade reading level (see infra Table 5).

If a question was perceived to have a socially desirable answer, it was asked in a manner designed to require jurors to actively deny a socially undesirable response rather than passively affirm a socially desirable response. Social desirability was also controlled for by adding a disclaimer designed to solicit honesty and openness prior to asking the questions, per the Colorado method. ${ }^{122}$

This exploratory statute continues to allow capital defense attorneys the freedom to conduct business as usual. Although the research demonstrates states require updated death qualification statutes, this updated statute should not disrupt operating procedures defense attorneys have spent a lifetime developing and honing. Instead, an updated statute is necessary because state statutes in their current form heavily favor the prosecution and are known to bias juries toward both conviction and death sentences. ${ }^{123}$ This updated statute, then, should rectify the codified imbalance favoring the prosecution while simultaneously preserving defense attorneys' ability to practice current voir dire strategies. As one anonymous writer 124 points out, no simplistic statute can possibly address all of the complexities associated with death qualification. It is possible, however, to craft a statute which takes into account voir dire practices such as the Colorado method $^{125}$ which ensure all prospective jurors are vetted to the same minimum degree. This minimum threshold should never supplant a more thorough, one-on-one, private approach to voir dire questioning by defense attorneys, but appears necessary given the number of capital defendants who receive inadequate legal representation. ${ }^{126}$ An eventual model statute should recognize the importance of voir dire for obtaining a favorable trial outcome and require states to provide a minimum level of vetting to all prospective jurors in order to avoid penalizing capital defendants for incompetent legal representation. This solution is less than ideal, but offers capital defendants greater protections than they are currently afforded under existing state statutes.

\footnotetext{
${ }^{121}$ See Matthew Rubenstein, Overview of the Colorado Method of Voir Dire, CHAMPION, Nov. 2010, at 18.

122 Id.

${ }^{123}$ See Open Discussion: Capital Jury, supra note 4.

${ }^{124}$ We are indebted to both anonymous reviewers who provided comments on an earlier draft and whose insightful comments have helped shape this article into its current form.

${ }^{125}$ See Rubenstein, supra note 121.

${ }^{126}$ See Justice Backs Death Penalty Freeze, CBS News (Apr. 10, 2001), http://www.cbsnews.com/news/justice-backs-death-penalty-freeze/ (quoting Justice Ginsburg saying, "I have yet to see a death case among the dozens coming to the Supreme Court on eve-of-execution stay applications in which the defendant was well represented at trial.... People who are well represented at trial do not get the death penalty").
} 
Table 5: Readability Scores for the Exploratory Statute

\begin{tabular}{lll}
\hline Question \# & Flesch Reading Ease & Flesch-Kincaid Grade Level \\
\hline Disclaimer & 50.8 & 9.1 \\
1A & 75.7 & 7.1 \\
1B & 84.7 & 8.3 \\
1C & 69.7 & 10.2 \\
1D & 76.5 & 8.7 \\
1E & 72.3 & 8.1 \\
1F & 89.8 & 7.9 \\
1G & 78.7 & 9.2 \\
2A & 72.3 & 8.1 \\
2B & 69.7 & 10.2 \\
2C & 78.7 & 9.2 \\
Full-Length Statute & 49.6 & 12.7 \\
\hline
\end{tabular}

\section{B. An Exploratory Statute}

In a capital trial, all prospective jurors are required to answer the following questions in the order presented below before serving as a juror. These questions may be presented and answered as a written survey in the presence of other prospective jurors, or asked verbally of each individual juror during a private, sequestered meeting where only a single prospective juror, the trial judge, the defense attorney, and the prosecutor are present. Before the questions are presented, jurors must be presented with the following disclaimer:

You are going to be asked a few questions. There are no 'right' or 'wrong' answers. People in our community have different opinions on many topics, and jurors also have different opinions. Having different opinions is a healthy part of democracy, and important for solving challenges our country faces. The court asks you answer as honestly and clearly as possible.

Question 1A: If you found someone guilty of murder, would your first thought be to give them the death penalty?

Question 1B: Would your first thought be to give them the death penalty if you could have them spend the rest of their life in prison with no way out?

Question 1C: If you found someone guilty of murder, would you feel like you owe it to the victim or their loved ones to give them the death penalty?

Question 1D: Would you ever have someone spend the rest of their life in prison with no way out for murder if you could give them the death penalty?

Question 1E: If you found someone guilty of murder, would you try to find reasons not to give them the death penalty?

Question 1F: If you had to pick between doing what you think is right and what the law says is right, would you choose to do what you think is right?

Question 1G: If you thought the law told you not to give the death penalty, but your heart told you to give the death penalty, would you follow your heart? 
Prospective jurors who answer question $1 \mathrm{D}$ or $1 \mathrm{E}$ in the negative, or $1 \mathrm{C}, 1 \mathrm{~F}$ or $1 \mathrm{G}$ in the affirmative, are to be disqualified from jury service for the present capital trial. All prospective jurors who were not disqualified from jury service based on their answers to questions 1C, 1D, 1E, $1 \mathrm{~F}$, or $1 \mathrm{G}$ are also to answer the following questions:

Question 2A: If you found someone guilty of murder, would your first thought be to stop them from getting the death penalty?

Question 2B: Would you ever think about giving someone the death penalty if you could have them spend the rest of their life in prison with no way out?

Question 2C: If you thought the law told you to give the death penalty, but your heart told you to not give the death penalty, would you follow your heart?

Prospective jurors who answer question $2 \mathrm{~B}$ in the negative or $2 \mathrm{C}$ in the affirmative are to be disqualified from jury service for the present capital trial. Prospective jurors who are not disqualified based on their responses to question $1 C, 1 D, 1 E, 1 F, 1 G, 2 B$, or $2 C$ may be asked additional, juror-specific, sequestered questions by the trial judge, prosecutor, or defense attorney. It is recommended these additional questions be open-ended to allow jurors ample opportunity to respond without the restrictions imposed by the mandatory minimum questions. If for any reason confusion exists regarding the classification of a prospective juror's answer as negative or affirmative for one of the mandatory questions, the defense, prosecution, and judge may all follow up with as many additional, open-ended, oral questions aimed at clarifying the matter as necessary to establish with reasonable confidence whether the juror's answer is best understood as negative or affirmative. All follow up questions must be conducted in private with only the juror in question, the trial judge, the defense attorney, and the prosecutor present.

Prospective jurors are to be dismissed for cause and disqualified from jury service for the present capital trial if they hold views about the death penalty which would prevent or substantially impair their ability to:

(1) Follow the law regarding a determination of the capital defendant's innocence or guilt;

(2) Adequately consider mitigating circumstances during the sentencing phase according to the law;

(3) Recommend a sentence less than death; or

(4) Recommend a death sentence.

\section{Conclusion}

This research analyzed death-qualification statutes in the thirty-one U.S. states which still retain the death penalty. Findings revealed only half of those states directly address deathqualification, while three states lack statutes regulating death-qualification in any capacity. Over $75 \%$ of states which directly address death-qualification incorporate language associated with a now outdated Supreme Court decision, and fail to specify that jurors who are substantially impaired in their ability to follow the law should be disqualified. No statute explicitly states prospective jurors should be disqualified if they would always support a death sentence, and over 75\% have death-qualification statutes which apply solely to jurors biased against the death penalty. Georgia and Texas have statutes which would disqualify jurors the Supreme Court has said 
cannot be excluded. State statutes vary over whether death penalty biases are grounds for disqualification if they would influence the guilt phase, sentencing phase, or both. Overall, greater clarity is needed to create state statutes which reflect the most recent Court decisions and leave no doubt over which jurors can and cannot be disqualified.

Despite evidence demonstrating current death-qualification standards result in juries more likely to convict and sentence defendants to death, ${ }^{127}$ many states retain statutes inadequately regulating capital disqualification practices. At least two states have statutes that appear not to conform to Court decisions. Many more have codified language explicitly singling out jurors who oppose capital punishment for disqualification while remaining silent about jurors who unequivocally support death. Given the current shifting attitudes about capital punishment, states need to be more proactive in the interest of justice in death penalty cases based on Court decisions. The path states choose has important implications for constitutional law in the United States and beyond.

Declaration of Conflicting Interests

The author declares no potential conflicts of interest with respect to the research, authorship, and/or publication of this article.

Funding

The author received no financial support with respect to the research, authorship, and/or publication of this article.

\section{Author Biography}

Alexander H. Updegrove is a Doctoral Research Assistant in the Department of Criminal Justice and Criminology at Sam Houston State University. He obtained a B.S. in Psychology from Kutztown University of Pennsylvania and an M.A. in Forensic Psychology from Marymount University.

Rolando v. del Carmen is a distinguished and Regents Professor, College of Criminal Justice, Sam Houston State University. He obtained B.A. and L.L.B. degrees from the Philippines, an M.C.L. from Southern Methodist University, an L.L.M. from the University of California-Berkeley, and a J.S.D. from the University of Illinois. He is the co-director of the Institute for Legal Studies in Criminal Justice at Sam Houston.

127 See Butler, supra note 69. 